\title{
MEMBACA SISTEM SPASIAL ARSITEKTUR TRADISIONAL DAN VERNAKULAR DENGAN STRATEGI PENELITIAN ETNOGRAFI
}

\author{
Redi Sigit Febrianto \\ Dosen Prodi Arsitektur, Fak. Teknik Sipil dan Perencanaan, ITN Malang \\ e-mail: redi sigit@lecturer.itn.ac.id \\ Debby Budi Susanti \\ Dosen Prodi Arsitektur, Fak. Teknik Sipil dan Perencanaan, ITN Malang \\ e-mail:budisusantidebby@gmail.com \\ Maria Istiqoma \\ Dosen Prodi Arsitektur, Fak. Teknik Sipil dan Perencanaan, ITN Malang \\ e-mail: maria istiqoma@lecturer.itn.ac.id
}

\begin{abstract}
ABSTRAK
Tulisan ini berusaha untuk mendeskripsikan strategi penelitian etnografisebagai satu dari lima strategi penelitian Cresswell-dengan menggunakan tiga contoh etnis agraris di nusantara Indonesia. Etnis di nusantara Indonesia sangat beragam, namun publikasi arsitektur tradisional dan arsitektur vernakular Indonesia sebagai etnis agraris kurang tergali dengan baik. Etnografi adalah strategi riset penelitian yang berfungsi untuk memahami transfomasi budaya, sehingga dapat menginformasikan teori ikatan budaya dan diakhiri dengan membuat kesimpulan budaya pada suatu etnis. Penelitian terdahulu hanya mendekripsikan etnografi secara umum, tidak mendiskripsikan contoh etnis agraris di nusantara Indonesia. Tulisan ini berbeda, karena berusaha menunjukkan sistem spasial pada tiga etnis agraris Indonesia yaitu dengan eksistensi artefak berupa tempat penyimpanan hasil panen (lumbung). Tulisan ini tidak mengkhususkan diri pada stylistic system dan physical system, namun pada spatial system. Strategi penelitian pada tulisan ini berjenis deskriptif, yaitu berusaha menceritakan pemahaman etnografi pada riset arsitektur tradisional dan vernakular. Metode pengumpulan data berasal dari jurnal ilmiah tentang etnis agraris Indonesia dan buku teori etnografi. Metode analisa data menggunakan komparasi antar jurnal ilmiah tentang etnografi berdasarkan eksistensi artefak tiga perwakilan etnis agraris Indonesia. Temuan penelitian ini berupa kategorisasi artefak dari tiga etnis sebagai unsur utama dari strategi penelitian etnografi.
\end{abstract}

Kata kunci: etnis agraris; kesimpulan budaya; lumbung; artefak

\section{PENDAHULUAN}

Etnis nusantara pada tulisan ini merujuk pada konsep Boelaars yaitu "mentalitas pola-pola kebudayaan masyarakat Indonesia" (Boelaars, 1984). Konsep dari Boelaars membagi masyarakat Indonesia sebagai masyarakat agraris menjadi empat jenis yaitu: (1) masyarakat petani sawah; (2) masyarakat petani ladang; (3) masyarakat pesisir dan (4) masyarakat perantau. Etnis agraris tersebut akan membentuk arsitektur tradisional dan

PAWON: Jurnal Arsitektur, Volume II Nomor 02, Juli-Desember 2018, ISSN 2597-7636 
arsitektur vernakular dengan artefak yang berbentuk lumbung atau tempat penyimpanan panen, sehingga pantas disebut sebagai arsitektur lumbung (Kusdiwanggo, 2011). Namun publikasi riset arsitektur tradisional dan arsitektur vernakular dari etnis di Indonesia kurang digali dengan baik. Etnografi-sebagai satu dari lima strategi penelitian Cresswell-adalah strategi riset penelitian yang berfungsi untuk memahami culture-sharing, sehingga dapat menginformasikan culture bound dan diakhiri dengan membuat kesimpulan budaya pada sistem spasialnya pada ranah arsitektural.

Tulisan ini berbeda, karena berusaha menunjukkan sistem spasial pada tiga etnis agraris Indonesia yaitu dengan eksistensi artefak berupa tempat penyimpanan hasil panen (lumbung). Tulisan ini tidak mengkhususkan diri pada stylistic system dan physical system, Tulisan ini berusaha untuk mendeskripsikan strategi penelitian etnografi-sebagai satu dari lima strategi penelitian Cresswell-dengan menggunakan tiga contoh etnis agraris di nusantara Indonesia.

\section{TINJAUAN PUSTAKA}

\subsection{Definisi Etnografi}

Strategi penelitian etnografi pada tulisan ini mengacu pada buku dari Spradley (2007) yang berjudul "Metode Etnografi". Buku tersebut hanya mendekripsikan etnografi secara umum, namun tidak menunjukkan kesimpulan budaya berdasarkan eksistensi artefak-berupa lumbung sebagai tempat penyimpanan panen-dari masyarakat agraris di nusantara Indonesia. Artefak merupakan salah kategorisasi utama strategi penelitian etnografi.

Etnografi adalah satu dari lima strategi penelitian yang disebutkan oleh Cresswell pada bukunya yang berjudul "Research design: Pendekatan kualitatif, kuantitatif dan mixed", empat lainnya yaitu: strategi naratif, strategi grounded theory, strategi fenomenologi dan strategi studi kasus. Strategistrategi penelitian lain juga ada dan sudah banyak dibahas secara meyakinkan dalam buku-buku kualitatif, seperti penelitian tindakan partisipatoris (Kemmis \& Wilkinson, 1998 dalam Creswell, 2010) atau analisis wacana (Cheek, 2004 dalam Creswell, 2010). Khusus untuk lima pendekatan tadi, para peneliti dapat mengkaji individu-individu (dengan naratif atau fenomenologi); mengeksplorasi proses, aktivitas, dan peristiwaperistiwa (dengan studi kasus atau grounded theory); atau mempelajari perilaku culture-sharing dari individu-individu atau kelompok-kelompok tertentu (dengan etnografi). (Creswell, 2010)

Sejarah etnografi dibagi menjadi empat bagian, yaitu: etnografi awal, etnografi modern, etnografi baru dan etnografi baru ala Spradley (Spradley,

PAWON: Jurnal Arsitektur, Volume II Nomor 02, Juli-Desember 2018, ISSN 2597-7636 
2007). Etnografi awal dipelopori oleh W.H.R Rivers dari Inggris dan Franz Boaz dari Amerika Serikat, mempunyai ciri yaitu informan oriented. Etnografi awal bertujuan mendapatkan gambaran masa lalu masyarakat asli (native), bukan masa kini. Etnografi modern dipelopori oleh AR Radcliffe-Brown \& Bronislaw Malinowski. Etnografi modern mempunyai ciri yaitu memahami way of life native kehidupan masa kini, bukan sejarah kebudayaan masa lalu. Etnografi baru dipelopori oleh Ward Goodenough, sering disebut sebagai ethnoscience (etnosains) atau cognitive anthrophology (etnografi baru). Etnografi baru bertujuan menemukan dan menggambarkan bagaimana organisasi pikiran dari struktur sosial budaya tersebut dan kemudian menggunakannya tersebut dalam kehidupan. Etnografi baru ala James P. Spradley menggunakan metode yang disebut the developmental research sequence method atau metode alur penelitian maju bertahap yang membedakan dari ketiga jenis etnografi lainnya.

Etnografi sebagai satu dari lima strategi penelitian riset arsitektur Cresswell, secara umum bertujuan memahami budaya dan perilaku pada sekelompok rumpun manusia. Secara khusus berfungsi untuk memahami tranformasi budaya (culture-sharing), sehingga dapat menginformasikan teori ikatan budaya (culture bound) dan diakhiri dengan membuat kesimpulan budaya pada etnis nusantara Indonesia (Spradley, 2007)

\subsection{Definisi Sistem Spasial pada Etnografi}

Sistem spasial pada tulisan ini merujuk pada konsep dari Habraken, yaitu dalam mengenali produk arsitektur dapat melalui tiga sistem yaitu: (1) stylistic system (sistem bentuk atau model bangunan); (2) physical system (sistem bahan dan struktur elemen pembentuk bangunan) dan (3) spatial system (sistem organisasi ruang pada bangunan) (Habraken, 1978). Tulisan ini tidak mengkhususkan diri pada stylistic system dan physical system, namun pada spatial system.

Arsitektur sendiri dapat dilihat dari tiga sistem yaitu: (1) stylistic system (sistem bentuk atau model bangunan), (2) physical system (sistem bahan dan struktur elemen pembentuk bangunan) dan (3) spatial system (sistem organisasi ruang pada bangunan) (Habraken, 1978). Etnografi dapat memahami tranformasi budaya (culture-sharing), membentuk teori ikatan budaya (culture bound) dan membuat kesimpulan budaya berdasarkan ketiga sistem tersebut. Etnis agraris tersebut akan membentuk arsitektur tradisional dan arsitektur vernakular dengan artefak yang berbentuk lumbung atau tempat penyimpanan panen, sehingga pantas disebut sebagai arsitektur lumbung (Kusdiwanggo, 2011).

\subsection{Definisi Arsitektur Tradisional dan Arsitektur Vernakular}

Definisi arsitektur tradisional dan arsitektur vernakular pada tulisan ini merujuk pada pendapat Febrianto, yaitu membedakan keduanya 
berdasarkan lima unsur yaitu: perancang bangunan; dasar pembangunan; konsep pembangunan; teknik membangun dan setting bangunan (Febrianto, 2017).

Tabel 1. Komparasi arsitektur tradisional dan arsitektur vernakular

\begin{tabular}{ccc}
\hline Unsur & arsitektur tradisional & arsitektur vernakular \\
\hline Perancang bangunan & $\begin{array}{c}\text { Masyarakat lokal, bukan masyarakat } \\
\text { adat }\end{array}$ & $\begin{array}{c}\text { Masyarakat adat, bukan amsyarakat } \\
\text { lokal }\end{array}$ \\
\hline $\begin{array}{c}\text { Kasar pembangunan } \\
\text { pembangunan }\end{array}$ & Berdasarkan fungsi, bukan adat & $\begin{array}{c}\text { Berdasarkan adat, kepercayaan, } \\
\text { budaya, dan kosmologi, bukan fungsi }\end{array}$ \\
\hline Teknik membangun & $\begin{array}{c}\text { Mengutamakan local knowledge, } \\
\text { local material, serta local technology }\end{array}$ & $\begin{array}{c}\text { Mengutamakan konsep } \\
\text { berdasarkan kesepakatan warga adat }\end{array}$ \\
\hline Setting bangunan & $\begin{array}{c}\text { Dibuat berdasarkan setting } \\
\text { lingkungan tempat bangunan tersebut } \\
\text { didirikan }\end{array}$ & $\begin{array}{c}\text { Dibuat berdasarkan setting } \\
\text { lingkungan, dan disepakati ketua } \\
\text { masyarakat adat }\end{array}$ \\
\hline
\end{tabular}

Sumber: (Febrianto, 2017).

\section{METODE PENELITIAN}

Metode pengumpulan data berasal dari jurnal ilmiah tentang etnis agraris Indonesia dan buku teori etnografi. Metode analisa data menggunakan komparasi antar jurnal ilmiah tentang etnografi berdasarkan eksistensi artefak tiga perwakilan etnis agraris Indonesia. Temuan penelitian ini berupa kategorisasi artefak dari tiga etnis sebagai unsur utama dari strategi penelitian etnografi.

Adapun perwakilan tiga etnis tersebut adalah: masyarakat peladang jagung dari Madura provinsi Jawa Timur (Febrianto et al., 2017a); masyarakat petani sawah dari Ciptagelar dari provinsi Jawa Barat (Kusdiwanggo, 2012) dan suku Talang Mamak dari provinsi Riau (Faisal \& Wihardyanto, 2014).

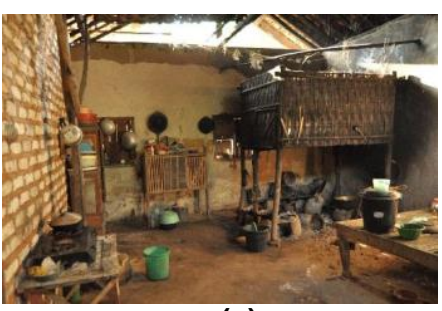

(a)

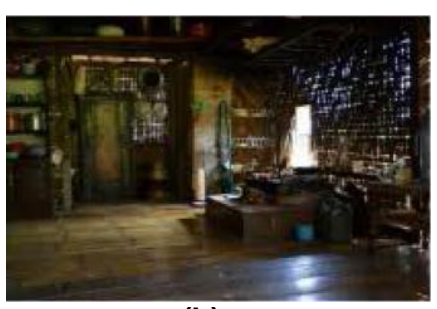

(b)

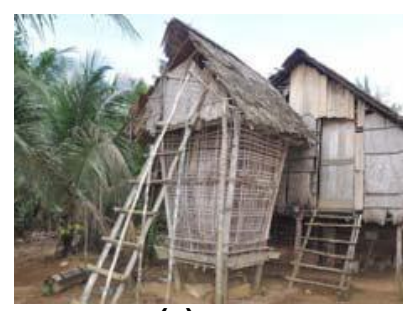

(c)

(A) Artefak penyimpanan jagung di Madura Timur disebut jhuurung dan bhuudeg (Febrianto et al., 2017a); (B) Artefak penyimpanan padi di Ciptagelar disebut pangdaringan (Kusdiwanggo, 2012); (C) Artefak sebagai penyimpanan padi pada suku Talang Mamak di Riau disebut rangkiang padi (Faisal \& Wihardyanto, 2014) 


\section{HASIL DAN PEMBAHASAN}

Etnografer membuat kesimpulan budaya dari tiga sumber, yaitu: (1) wawancara; (2) observasi; (3) artefak yang dibentuk oleh etnis agraris tersebut. Kesimpulan budaya berdasarkan sistem spasial (bukan sistem fisik maupun sistem model) dapat dilihat berdasarkan eksistensi artefaknya. Adapun eksistensi artefak suku dan ras asli Indonesia sebagai negara agraris perwujudannya berupa lumbung atau tempat penyimpanan hasil panen. Lumbung atau tempat penyimpanan panen dapat dikategorikan sebagai agriculture vernacular architecture (Kusdiwanggo, 2011). Setiap etnis di Indonesia memiiki nama, rupa dan bentuk tempat penyimpanan panen yang sangat beragam.

Tempat penyimpanan panen jagung masyarakat peladang Madura timur disebut jhuurung dan bhuudeg (Febrianto et al., 2017a, 2017b, 2017c). Tempat penyimpanan panen padi masyarakat Ciptagelar disebut pangdaringan (Kusdiwanggo, 2012). Tempat penyimpanan panen padi suku Talang Mamak disebut barkas / belubur / rangkiang padi (Faisal \& Wihardyanto, 2014). Oleh sebab itu tempat penyimpanan panen adalah artefak utama sebagai kategorisasi strategi penelitian etnografi dalam menjelaskan sistem spasial dari sebuah etnis.

Tabel 2. Komparasi kasus studi terpilih (sample)

\begin{tabular}{|c|c|c|c|c|}
\hline No & Aspek & $\begin{array}{c}\text { Kasus Studi } 1 \\
\text { (Febrianto et al., } \\
\text { 2017a) }\end{array}$ & $\begin{array}{c}\text { Kasus Studi } 2 \\
\text { (Kusdiwanggo, 2012) }\end{array}$ & $\begin{array}{c}\text { Kasus Studi } 3 \\
\text { (Faisal \& Wihardyanto, } \\
\text { 2014) }\end{array}$ \\
\hline 1 & Subyek Amatan & $\begin{array}{l}\text { Masyarakat peladang } \\
\text { jagung Madura Timur } \\
\text { (masyarakat tradisonal) }\end{array}$ & $\begin{array}{l}\text { Masyarakat petani } \\
\text { sawah Ciptagelar } \\
\text { (masyarakat adat) }\end{array}$ & $\begin{array}{c}\text { Masyarakat petani sawah } \\
\text { Suku Talang Mamak } \\
\text { (masyarakat tradisonal) }\end{array}$ \\
\hline 2 & Unit Amatan & $\begin{array}{l}\text { fungsi; sifat; makna; } \\
\text { posisi; orientasi; jenis } \\
\text { batas; bentuk batas; } \\
\text { civitas; aktivitas; tata } \\
\text { nilai-tata laku; artefak }\end{array}$ & $\begin{array}{l}\text { pengalaman; domain; } \\
\text { hirarki; artefak }\end{array}$ & $\begin{array}{l}\text { pola; fungsi; kategori; } \\
\text { artefak }\end{array}$ \\
\hline 3 & $\begin{array}{l}\text { Rancangan } \\
\text { Penelitian }\end{array}$ & Kualitatif & Kualitatif & Kualitatif+Kuantitatif \\
\hline 4 & $\begin{array}{l}\text { Strategi } \\
\text { penelitian }\end{array}$ & Etnografi & Etnografi & Deskriptif tentang etnis \\
\hline 5 & $\begin{array}{l}\text { Metode } \\
\text { Pengumpulan } \\
\text { Data }\end{array}$ & $\begin{array}{l}\text { Wawancara mendalam; } \\
\text { observasi lapangan }\end{array}$ & $\begin{array}{l}\text { Wawancara; observasi } \\
\text { dan dokumentasi } \\
\text { arsitektur vernakular }\end{array}$ & $\begin{array}{l}\text { Wawancara mendalam; } \\
\text { observasi lapangan }\end{array}$ \\
\hline 6 & $\begin{array}{l}\text { Metode Analisa } \\
\text { Data }\end{array}$ & $\begin{array}{l}\text { Analisis tematik } \\
\text { Analisis psikologi - } \\
\text { arsitektur }\end{array}$ & $\begin{array}{c}\text { Analisis antropologis- } \\
\text { arsitektur }\end{array}$ & $\begin{array}{c}\text { Analisis tipo-morfologi } \\
\text { tentang variasi geometrik } \\
\text { dan variasi fungsi }\end{array}$ \\
\hline 7 & Artefak & $\begin{array}{c}\text { Tempat penyimpanan } \\
\text { jagung berupa: jhuurung } \\
\text { dan bhuudeg }\end{array}$ & $\begin{array}{l}\text { Tempat penyimpanan } \\
\text { padi berupa: } \\
\text { pangdaringan }\end{array}$ & $\begin{array}{l}\text { Tempat penyimpanan padi } \\
\text { berupa: rangkiang padi }\end{array}$ \\
\hline 8 & Makna etnografi & $\begin{array}{l}\text { berfungsi primer, } \\
\text { bersifat intim namun } \\
\text { tidak bermakna sakral }\end{array}$ & $\begin{array}{l}\text { berfungsi primer, } \\
\text { bersifat intim dan } \\
\text { bermakna sakral }\end{array}$ & $\begin{array}{l}\text { berfungsi primer, bersifat } \\
\text { semi-privat namun tidak } \\
\text { bermakna sakral }\end{array}$ \\
\hline
\end{tabular}

PAWON: Jurnal Arsitektur, Volume II Nomor 02, Juli-Desember 2018, ISSN 2597-7636 


\subsection{Subyek dan Unit Amatan}

Subyek amatan pada tulisan ini merujuk pada masyarakat agraris atau etnis yang mempunyai mata pencaharian agraris. Konsep etnis agraris pada tulisan ini mengacu pada konsep dari Boelaars (1984). Masyarakat peladang jagung Madura timur dan masyarakat petani sawah suku Talang Mamak diidentifikasi sebagai masyarakat tradisional, sedangkan masyarakat petani sawah Ciptagelar diidentifikasi sebagai masyarakat adat.

Unit amatan pada tulisan ini mengacu pada tema-tema empiris arsitektural, yaitu: pola; fungsi; sifat; makna; posisi; orientasi; batas; civitas; aktivitas; tata nilai-tata laku; artefak. Persamaan dari ketiga subyek amatan ini adalah eksistensi artefak.

\subsection{Rancangan dan Strategi Penelitian}

Ketiga kasus studi terpilih menggunakan rancangan penelitian kualitatif untuk mendapatkan "kedalaman" dalam mengumpulkan dan menganalisis data. Pada kasus studi terpilih ke-3 menggunakan rancangan kuantitatif pada bagian analisisnya.

Kasus studi terpilih ke-1 dan ke-2 menggunakan strategi penelitian etnografi, sedangkan kasus studi terpilih ke-3 menggunakan strategi deskriptif yang berkaitan tentang etnis. Ketiganya dapat dikelompokkan membahas mengenai etnis agraris disertai dengan dokumentasi artefaknya.

\subsection{Metode Pengumpulan dan Analisis Data}

Ketiga kasus studi terpilih menggunakan metode pengumpulan data berciri rancangan kualitatif yaitu: wawancara mendalam dan observasi lapangan.

Ketiga kasus studi terpilih menggunakan metode analisis data yang berbeda-beda satu dengan lainnya. Kasus studi pertama menggunakan analisis tematik dan analisis psikologi-arsitektur (Febrianto et al., 2017a). Analisis tematik berfungsi menemukan indikator, unit amatan, tema-tema, kategori dan konsep dari masyarakat peladang jagung Madura timur. Metode analisis psikologi-arsitektur berfungsi mengkonfirmasi melalui wawancara kreatif berdasarkan 10 tanda psikologi. Dengan kedua analisis tersebut menghasilkan konsep konstruksi dan nilai teritori ruang pada hunian masyarakat peladang Madura timur.

Kasus studi kedua menggunakan analisis antropologis-arsitektur, yaitu sistem keruangan dipahami sebagai jenis topologis yang dilihat dalam tiga subtipe yaitu place, environment, dan landscape. Analisis tersebut menghasilkan konsep habitat, yaitu perpaduan dari ketiga subtipo-topologis pada hunian masyarakat Ciptagelar. 
Kasus studi ketiga mengggunakan analisis induktif Analisis tipomorfologi tentang variasi geometrik dan variasi fungsi pada bangunan guna menemukan karakteristik tata ruang bangunan rumah tinggal Suku Talang Mamak. Analisis tersebut menghasilkan konsep tipologi geometrik dan morfologi fungsi tambahan pada hunian suku Talang Mamak.

\subsection{Eksistensi Artefak dan Makna}

Sebagai bagian dari etnis agraris, ketiga kasus studi terpilih menggunakan artefak aktif berupa tempat penyimpanan panen. Atefak aktif tersebut merupakan kategorisasi bahwa penelitian tersebut menggunakan strategi penelitian etnografi.

Makna eksistensi artefak pada masyarakat peladang madura timur berupa tempat penyimpanan jagung (jhuurung dan bhuudeg) yaitu: berfungsi primer, bersifat intim namun tidak bermakna sakral. Berfungsi primer karena bagian dari masyarakat konsumsi jagung (maize eaters) (Febrianto et al., 2017b; Nawiyanto, 2011). Bersifat intim karena merupakan area yang sangat tertutup dan terbatas untuk orang luar. Tidak bermakna sakral karena sesuai ajaran Islam, yaitu tidak menyembah selain Allah S.W.T.

Makna eksistensi artefak pada masyarakat petanis sawah Ciptagelar berupa tempat penyimpanan padi (pangdaringan) yaitu: berfungsi primer, bersifat intim dan bermakna sakral. Berfungsi primer karena merupakan bagian dari budaya padi (rice culture) (Kusdiwanggo, 2012). Bersifat intim karena merupakan area yang sangat tertutup dan terbatas untuk orang luar. Bermakna sakral karena dianggap sebagai sesuatu yang suci.

Makna eksistensi artefak pada masyarakat petani sawah suku Talang Mamak berupa tempat penyimpanan padi ( rangkiang padi) yaitu: berfungsi primer, bersifat semi-privat namun tidak bermakna sakral. Berfungsi primer karena merupakan bagian dari budaya padi. Bersifat semi-privat karena terletak pada area ruang keluarga dan lebih bersifat tertutup, namun tidak terbatas. Tidak bermakna sakral karena bukan merupakan sesuatu yang suci dan patut diagungkan.

\section{KESIMPULAN}

Terdapat setidaknya delapan aspek untuk mengetahui apakah sebuah penelitian menggunakan strategi etnografi atau tidak. Namun yang paling penting dari kedelapan aspek tersebut adalah eksistensi artefak dan makna artefak. Keduanya merupakan kategorisasi utama dalam sebuah penelitian dengan strategi etnografi. Eksistensi artefak tetap nampak baik pada arsitektur tradisonal maupun arsitektur vernakular, sehingga penelitian keduanya dianggap cocok menggunakan strategi penelitian etnografi. 


\section{DAFTAR PUSTAKA}

Boelaars, J. H. M. C. (1984). Kepribadian Indonesia Modern: Suatu Penelitian Antropologi Budaya. Jakarta: Gramedia.

Creswell, J. (2010). Research Design; Pendekatan Kualitatif, Kuantitatif dan Mixed. Yogyakarta: Pustaka Pelajar.

Faisal, G., \& Wihardyanto, D. (2014). Studi Tata Ruang Rumah Tinggal Suku Talang Mamak. JURNAL TESA ARSITEKTUR, Vol. XII no. 2 Desember 2014, Hal.97-104.

Febrianto, R. S. (2017). Teritori Ruang Pada Lanskap-Hunian Masyarakat Peladang Desa Juruan Laok Madura Timur. (Tesis), Universitas Brawijaya, Malang.

Febrianto, R. S., Wulandari, L. D., \& Santosa, H. (2017a). Domain Ruang Perempuan Pada Hunian Masyarakat Peladang Desa Juruan Laok Madura Timur. JURNAL TESA ARSITEKTUR, Volume 15 (Nomor 1), 54-63. doi:https://doi.org/10.24167/tes.v15i1.1014 (http://journal.unika.ac.id/index.php/tesa/article/view/1014)

Febrianto, R. S., Wulandari, L. D., \& Santosa, H. (2017b). Pola Spasial Teritori Pada Lanskap-Hunian Masyarakat Peladang Desa Juruan Laok Madura Timur. Jurnal Teknik Arsitektur ARTEKS, Volume 2 (Nomor 1, Desember 2017). doi: http://dx.doi.org/10.30822/artk.v2i1.140

Febrianto, R. S., Wulandari, L. D., \& Santosa, H. (2017c). Spasial Ruang Pada Hunian Masyarakat Peladang-Muslim Desa Juruan Laok Madura Timur. Jurnal Modul, Volume 17 (No 1 Januari Juni 2017), 110. doi:https://doi.org/10.14710/mdl.17.1.2017.1-10

Habraken, N. J. (1978). General Principles A Bout the Way Built Environment Exist. Massachusetts: MIT Press.

Kusdiwanggo, S. (2011, 26 Maret 2011). Aspek Gender Pada Arsitektur Lumbung. Paper presented at the Prosiding Seminar Nasional 2011 Akrab Lingkungan, Kearifan Lokal dan Kemandirian, Hotel Santika Permier Malang.

Kusdiwanggo, S. (2012). Peran dan Pengaruh Kultur Padi pada Pola Ruang-

Tempat Hunian Masyarakat Ciptagelar. Paper presented at the

Prosiding Seminar Nasional Riset Arsitektur dan Perencanaan:

Sistem Spasial pada Seting Lingkungan Kehidupan.

Nawiyanto. (2011). Konsepsi Sosio Kultural Etnis Jawa dan Madura di Eks-

Karesidenan Besuki tentang Pangan. Jurnal Humaniora, Vol 23, No 2, Hal.125-139.

Spradley, J. P. (2007). Metode Etnografi (M. Z. Elizabeth, Trans. M. Yahya Ed.). Yogyakarta: Tiara Wacana. 